\title{
Performance of pummelo clones in the central mountain region of Puerto Rico'
}

\author{
Arturo Cedeño-Maldonado," Wigmar González \\ and Eleanor Fontanet:
}

\begin{abstract}
Studies were conducted in the central mountainous region of Puerto Rico to defermine the adaptability of 18 pummelo clones. Data on fruit number, weight and yield efficiency were collected during three consecutive crop years beginning the fourth year after planting. Clones Dry Pink, Thong Dee White and African Seedling were the best in terms of total number of fruits produced per tree. Production increased with age from over forty fruits for four-year-old trees to over sixty fruits per tree for sixyear-old trees. Fruit weight per tree also increased with age, reaching a maximum of $87 \mathrm{~kg}$ of fruit for six-year-old trees. Clones Dry Pink and Thong Dee White were the best in terms of total fruit weight. Yield efficiency measured in terms of number of fruits per $\mathrm{cm}$ of stem diameter also increased with age from an average of 5.50 for four-year-old trees to 7.55 for six-year-old trees. Best yield efficiency was obtained with clones Dry Pink, Reinking, Thong Dee White and Green Favorite. These results indicate an excellent adaptability of the pummelo to the soil and climate conditions prevailing in the central mountainous region of Puerto Rico.
\end{abstract}

\section{RESUMEN}

Comportamiento de clones de pomelo en la zona montañosa central de Puerto Rico

Se estudió la adaptabilidad de 18 clones de pomelo. Se tomaron datos sobre el número y el peso de las frutas y la eficienca de rendimiento por 3 años en árboles que inicialmente tenían 4 años de establecidos, la producción de frutas por árbol fue superior en los clones Dry Pink, Thong Dee White y African Seedling. El número de frutas producidas por árbol aumentó con la edad, de más de 40 frutas en árboles de 4 años a más de 60 frutas en árboles de 6 años. El peso de las frutas por árbol también aumentó con la edad hasta un máximo de más de $87 \mathrm{~kg}$ en árboles de 6 años. Los clones Dry Pink y Thong Dee White fueron los mejores en término del peso de las frutas por árbol. La eficiencia en rendimiento determinada a base del número de frutas por centímetro de diámetro del tallo también aumentó con la edad de un promedio de 5.50 en árboles de 4 años a 7.55 en árboles de 6 años. La mejor eficiencia en rendimiento se obtuvo con los clones de Dry Pink, Reinking, Thong Dee White y Green Favorite. Estos resultados demuestran una excelente adaptabilidad del pomelo a las condiciones de suelo y clima prevalecientes en la zona montañosa del centro de Puerto Rico.

'Manuscript submitted to Editorial Board 5 May 1989.

'Professor, Department of Horticulture.

${ }^{3}$ Research Assistant, Department of Horticulture.

"Assistant Statistician, Statistics Section. 


\section{INTRODUCTION}

The pummelo, Citrus grandis (L.) Osbeck, is a fruit of commercial importance in several countries of the Asian continent, including Thailand, Malaysia and Vietnam. ${ }^{5}$ The date of its introduction to tropical America is uncertain, but it is supposed to have been introduced to the West Indies before its introduction to the United States in the early $1900 \mathrm{~s}^{6}{ }^{6}$ Although it grows well in the subtropics, the quality of fruits is better when grown in tropical environments. ${ }^{5}$

It is not known when the pummelo was first introduced to Puerto Rico, but before 1978 only the variety Tresca was known to exist on the island as a mature tree. ${ }^{5}$ In the 1970 s several pummelo introductions were made by the USDA-ARS Station in Mayagüez and planted there for preliminary evaluation. The most promising trees were selected for further propagation as clones and provided the propagation materials used in the present study. This study was conducted with the purpose of determining the adaptability and production potential of the pummelo in the central mountain region of Puerto Rico, where citrus fruits are an important crop.

\section{MATERIALS AND METHODS}

Experiments were conducted at the Adjuntas Agricultural Substation in the central mountainous region of Puerto Rico. The climate in the area is characterized by a rainy season extending from August to November and a dry season from January to May, with an average annual precipitation of $1700 \mathrm{~mm} .^{7}$ The soil type in the area is an Alonso clay, a light, friable, fertile soil belonging to the Orthoxic Tropohumults subgroup.

The plant material for the experiment consisted of 18 pummelo clones selected for superior yield and desirable fruit characteristics (table 1). Budwood of the clones was obtained from adult trees in a variety collection established at USDA-TARS, Mayagüez, P. R. Clones were budded to seedlings belonging to the African pummelo variety. These seedlings were germinated in sand and transplanted to 2-gal plastic bags filled with topsoil. Budded trees were kept in the plastic bags until they were planted in the field approximately one year later.

Trees were planted August 1980 at a distance of $6.4 \times 7.6 \mathrm{~m}(20 \times 25$ feet). The experimental layout consisted of a partially balanced incomplete block arrangement with four replications. Seventy-two trees were planted to complete 18 blocks with four clones each and one tree per plot.

Martin, F. W. and W. C. Cooper, 1977, Cultivation of neglected tropical fruits with promise. The Pummelo Publication. ARS-157.

"Chandler, W. H., 1964. The pummelo and grapefruit-Evergreen Orchards- Lea and Febiges-Philadelphia, Pa. Pages 153-69.

${ }^{7}$ Pérez, A. and C. J. Torres, 1984. Growth, yield efficiency and fruit quality of five navel orange clones during four years. J. Agric. Univ. P. R.- 68: 405-41. 
TABLE 1.-List of pummelo varieties indicating source and pulp color

\begin{tabular}{lll}
\hline Variety & Source & \multicolumn{1}{c}{ Pulp color } \\
\hline Light Pink & Miami, Fla. & Pale green to cream yellow \\
Dry Pink & Miami, Fla. & Pale green to cream yellow \\
Thong Dee White & Texas & Cream-yellow \\
Wet Pink & Miami, Fla. & Pale Green to cream yellow \\
Red 16023 & Texas & Light pink \\
Reinking & Indio, CA & Cream-yellow \\
Green Favorite & Miami, Fla. & Cream-yellow-green \\
Thong Dee 16024 & Texas & Light Pink \\
Pink 9551 & Miami, Fla. & Intense Pink \\
Siamese & Orlando, Fla. & Cream-yellow-green \\
African Seedling & Indio-CA & Light Pink \\
Tresca & Isabela, P.R. & Medium pink-green \\
Father Jerome & Florida & Yellow-green-pink \\
Pink 9552 & Miami, Fla. & Cream-yellow-green \\
Chinese & Orlando, Fla. & Cream-yellow \\
Ogami & Orlando, Fla. & Medium pink \\
Isabela Hybrid & Isabela, P.R. & Medium pink \\
White 16026 & Miami, Fla. & Cream-yellow \\
\hline
\end{tabular}

Trees were cultivated according to standard practices recommended by the Agricultural Experiment Station of the University of Puerto Rico. ${ }^{8}$ No irrigation was provided and trees were hand-weeded when necessary.

From the fourth year after planting, data was collected on fruit production parameters such as number and size of fruits, internal and external color, juice content, seediness, appearance of central core, and on tree growth parameters such as trunk diameter, tree height and canopy width. Results here reported represent some of the data obtained from the three crops of 1984 to 1986.

\section{RESULTS AND DISCUSSION}

Table 2 shows data on average number of fruits per tree. There was little year to year fluctuation in production in most clones. This finding suggests the absence of biennial or alternate bearing in the pummelo. There was an increase in number of fruits per tree from 1984 to 1986. This increase can be attributed to young trees that continued to grow and enlarge the canopy during the 3-year period.

Cultivars Dry Pink, Thong Dee White and African seedling consistently produced more fruits per tree. Cultivars Wet Pink, Green Favorite, Thong Dee, Reinking, Pink 9252, Siamese and Father Jerome also produced well. Cultivars Pink 9551, Tresca, Ogami and Isabela Hybrid

${ }^{3}$ Estación Experimental Agrícola, 1987. Conjunto tecnologico para la producción de cítricas. Univ. P. R., Publ. 113. 
TABLE 2.-Average number of fruits produced per tree in three consecutive crops

\begin{tabular}{lccc}
\hline Variety & \multicolumn{1}{c}{1984} & 1985 & 1986 \\
\hline Light Pink & $21.30 \mathrm{abcd}$ & $27.43 \mathrm{ab}$ & $32.80 \mathrm{abcde}$ \\
Dry Pink & $48.13 \mathrm{a}$ & $43.89 \mathrm{a}$ & $52.03 \mathrm{abc}$ \\
Thong Dee White & $37.37 \mathrm{ab}$ & $25.40 \mathrm{abc}$ & $66.21 \mathrm{a}$ \\
Wet Pink & $32.73 \mathrm{abc}$ & $29.70 \mathrm{ab}$ & $27.25 \mathrm{bcde}$ \\
Red 16023 & $13.90 \mathrm{abcd}$ & $7.14 \mathrm{bc}$ & $29.08 \mathrm{bcde}$ \\
Reinking & $32.15 \mathrm{abc}$ & $34.24 . \mathrm{ab}$ & $31.71 \mathrm{abcde}$ \\
Green Favorite & $31.33 \mathrm{abc}$ & $21.42 \mathrm{abc}$ & $18.84 \mathrm{bcde}$ \\
Thong Dee & $7.58 \mathrm{bcd}$ & $36.35 \mathrm{ab}$ & $41.98 \mathrm{abcd}$ \\
Pink 9551 & $4.64 \mathrm{~cd}$ & $16.01 \mathrm{bc}$ & $14.50 \mathrm{cde}$ \\
Siamese & $23.78 \mathrm{abcd}$ & $11.68 \mathrm{bc}$ & $34.99 \mathrm{abcde}$ \\
African & $28.22 \mathrm{abc}$ & $19.95 \mathrm{abc}$ & $52.34 \mathrm{ab}$ \\
Tresca & $0 \mathrm{~cd}$ & $4.45 \mathrm{bc}$ & 0 \\
Father Jerome & $27.55 \mathrm{abcd}$ & $21.37 \mathrm{abc}$ & $15.89 \mathrm{bcde}$ \\
Pink 9552 & $14.48 \mathrm{abcd}$ & $24.18 \mathrm{abc}$ & $27.60 \mathrm{bcde}$ \\
Chinese & $14.67 \mathrm{abcd}$ & $10.84 \mathrm{bc}$ & $18.29 \mathrm{bcde}$ \\
Ogami & $1.38 \mathrm{~cd}$ & $8.47 \mathrm{bc}$ & $12.83 \mathrm{de}$ \\
Isabela Hybrid & $0 \mathrm{~d}$ & $0.08 \mathrm{c}$ & $9.44 \mathrm{de}$ \\
White 16026 & $32.74 \mathrm{abc}$ & $13.09 \mathrm{bc}$ & $31.50 \mathrm{abcde}$ \\
\hline
\end{tabular}

'Means in columns followed by the same letter do not differ significantly at the $5 \%$ probability level.

produced the fewest fruits per tree. Maximum production was 48,44 and 66 fruits per tree for 4-, 5-, and 6-year-old trees, respectively. Fruit count per tree is an important parametr since these large-sized fruits are usually sold on a fruit-unit basis.

Table 3 shows data on fruit weight. A pattern similar to that in fruit number was observed in weight of fruits per tree, which increased with age without marked year to year fluctuations. Cultivars Dry Pink, Thong Dee White, Wet Pink and Reinking were superior in terms of total average weight of fruit per year, with a significantly higher fruit weight during the 3 years. Fruits of cultivars Light Pink, Green Favorite, Thong Dee, African Seedling, Pink 9552 and White 16026 were bigger than those of cultivars Pink 9551, Tresca, Ogami and Isabela hybrid, which were the lowest in terms of fruit weight. Maximum yield obtained was $87.5 \mathrm{~kg}$ per tree for 6-year-old Dry Pink trees.

Table 4 shows yield efficiency calculated as number of fruit per $\mathrm{cm}$ of stem diameter. There were no marked differences in yield efficiency during the 3 years studied, probably because of the use of the same rootstock for grafting all the clones. There were no signs of incompatability. The significant differences observed within years could have resulted from differences in canopy development in young trees. The average efficiencies observed, $5.50,5.47$ and 7.55 fruits per $\mathrm{cm}$ of stem diamter for trees 4,5 , and 6 years old, respectively, could serve as reference 
TABLE 3.-Average fruit weight in kilograms per tree in three consecutive crops

\begin{tabular}{|c|c|c|c|}
\hline Variety & 1984 & 1985 & 1986 \\
\hline Light Pink & $28.80 \mathrm{bcd}^{1}$ & $38.50 \mathrm{abc}$ & $51.20 \mathrm{abc}$ \\
\hline Dry Pink & $80.97 \mathrm{a}$ & 70.57 a & $87.56 \mathrm{a}$ \\
\hline Thong Dee White & $50.27 \mathrm{ab}$ & $32.43 \mathrm{abc}$ & $82.73 \mathrm{a}$ \\
\hline Wet Pink & $48.03 \mathrm{abc}$ & $44.73 a b c$ & $40.05 \mathrm{abcd}$ \\
\hline Red 16023 & $17.75 \mathrm{bed}$ & $6.90 c$ & $35.68 \mathrm{abcd}$ \\
\hline Reinking & $43.05 \mathrm{abc}$ & $48.32 \mathrm{ab}$ & $44.05 \mathrm{abc}$ \\
\hline Green Favorite & $35.15 \mathrm{abcd}$ & $34.71 a b c$ & $34.89 \mathrm{bcd}$ \\
\hline Thong Dee & $8.26 \mathrm{bcd}$ & $45.02 \mathrm{ab}$ & $52.71 \mathrm{abc}$ \\
\hline Pink 9551 & $6.88 \mathrm{~cd}$ & $25.19 \mathrm{abc}$ & $22.70 \mathrm{bcd}$ \\
\hline Siamese & $29.41 \mathrm{bcd}$ & $13.88 \mathrm{bc}$ & $39.62 \mathrm{abcd}$ \\
\hline African & $37.52 \mathrm{abcd}$ & $24.81 \mathrm{abc}$ & $62.10 \mathrm{ab}$ \\
\hline Tresca & $0 \quad \mathrm{~d}$ & $23.36 \mathrm{abc}$ & $0 \quad d$ \\
\hline Father Jerome & $24.63 \mathrm{bcd}$ & $22.27 \mathrm{bc}$ & $9.90 \mathrm{~cd}$ \\
\hline Pink 9552 & $24.14 \mathrm{bcd}$ & $37.50 \mathrm{abc}$ & $47.23 \mathrm{abc}$ \\
\hline Chinese & $28.84 \mathrm{bcd}$ & $20.00 \mathrm{bc}$ & $34.24 \mathrm{bc}$ \\
\hline Ogami & $5.78 \mathrm{~cd}$ & 12.75 be & $23.98 \mathrm{bcd}$ \\
\hline Isabela Hybrid & $3.76 \mathrm{~cd}$ & 8.85 bc & $30.26 \mathrm{bcd}$ \\
\hline White 16026 & $49.58 \mathrm{abc}$ & $16.18 \mathrm{bc}$ & $40.07 \mathrm{abcd}$ \\
\hline
\end{tabular}

${ }^{1}$ Means in columns followed by the same letter do not differ significantly at the $5 \%$ probability level.

TABLE 4.-Yield efficiency as to number of fruits per $\mathrm{cm}$ of stem diameter in three consecutive crops

\begin{tabular}{|c|c|c|c|}
\hline Variety & 1984 & 1985 & 1986 \\
\hline Light Pink & $5.16 \mathrm{abc}$ & $6.34 \mathrm{abc}$ & $8.55 \mathrm{a}$ \\
\hline Dry Pink & $11.96 \mathrm{a}$ & $10.45 \mathrm{a}$ & $13.21 \mathrm{a}$ \\
\hline Thong Dee White & $8.40 a b$ & $4.94 \mathrm{abc}$ & $12.75 a$ \\
\hline Wet Pink & $8.02 \mathrm{ab}$ & $7.76 \mathrm{abc}$ & $6.95 \mathrm{a}$ \\
\hline Red 16023 & $2.59 \mathrm{abc}$ & $1.15 \mathrm{c}$ & $6.43 \mathrm{ab}$ \\
\hline Reinking & $7.78 \mathrm{ab}$ & $8.35 \mathrm{ab}$ & $7.74 \mathrm{a}$ \\
\hline Green Favorite & $7.84 \mathrm{ab}$ & $8.13 \mathrm{ab}$ & $8.26 \mathrm{a}$ \\
\hline Thong Dee & $1.73 b c$ & $7.66 \mathrm{abc}$ & $9.24 \mathrm{a}$ \\
\hline Pink 955l & $2.13 b c$ & $5.10 \mathrm{abc}$ & $4.66 \mathrm{ab}$ \\
\hline Siamese & $5.69 \mathrm{abc}$ & $3.19 \mathrm{abc}$ & $7.85 \mathrm{a}$ \\
\hline African & $6.74 \mathrm{abc}$ & $4.44 \mathrm{abc}$ & $11.01 \mathrm{a}$ \\
\hline Tresca & $0 \quad c$ & $5.48 \mathrm{abc}$ & $0 \mathrm{~b}$ \\
\hline Father Jerome & $6.79 \mathrm{ab}$ & $6.29 \mathrm{abc}$ & $4,05 a b$ \\
\hline Pink 9552 & $4.72 \mathrm{abc}$ & $7.45 \mathrm{abc}$ & $10.27 \mathrm{a}$ \\
\hline Chinese & $5.59 \mathrm{abc}$ & $3.57 \mathrm{abc}$ & $6.24 a b$ \\
\hline Ogami & $3.01 \mathrm{abc}$ & $2.96 \mathrm{bc}$ & $5.33 \mathrm{ab}$ \\
\hline Isabela Hybrid & $2.14 \mathrm{bc}$ & $2.32 \mathrm{bc}$ & $6.63 \mathrm{ab}$ \\
\hline White 16026 & $8.70 \mathrm{ab}$ & $2.90 \mathrm{bc}$ & $6.76 \mathrm{ab}$ \\
\hline Average & 5.50 & 5.47 & 7.55 \\
\hline
\end{tabular}

'Means in columns followed by the same letter do not differ significantly at the $5 \%$ probability level. 
value for future studies of this fruit since no comparable figures are available in the literature.

Table 5 shows cumulative data on total average number of fruits per tree, total average fruit weight and yield efficiency. Clones Dry Pink and Thong Dee White produced the most fruits during the 3-year period. Clones Reinking and African ranked next. On a fruit weight basis, Dry Pink and Thong Dee White were also superior. Cultivars Light Pink, Wet Pink, Reinking and African were also outstanding in terms of fruit weight.

Average yield efficiency figures in table 5 indicate performance on the basis of tree size. All varieties performed almost equally. The best ones were Dry Pink, Reinking, Thong Dee White, Green Favorite and Wet Pink. Only Tresca was statistically inferior.

Results demonstrate an excellent adaptability of the pummelo to the central mountainous citrus growing area of Puerto Rico. Growth and tree development was excellent in almost all clones, and except for gum exudate in some trees no signs of diseases were observed.

Many factors should be considered in selecting and recommending a particular pummelo cultivar because of the multiple uses the fruit may

TABLE 5.-Total average fruit number and weight, and average yield index in three consecutive crops

\begin{tabular}{|c|c|c|c|}
\hline Variety & $\begin{array}{c}\text { Total } \\
\text { average } \\
\text { production }\end{array}$ & $\begin{array}{c}\text { Total } \\
\text { average } \\
\text { weight }\end{array}$ & $\begin{array}{c}\text { Average } \\
\text { yield } \\
\text { index }\end{array}$ \\
\hline & \multicolumn{3}{|c|}{$\mathrm{kg}$} \\
\hline Light Pink & $81.5 \mathrm{abc}^{\prime}$ & $118.5 \mathrm{abc}$ & $6.53 \mathrm{abc}$ \\
\hline Dry Pink & $144.0 \mathrm{a}$ & $239.0 \mathrm{a}$ & $11.83 \mathrm{a}$ \\
\hline Thong Dee White & $128.9 \mathrm{a}$ & $165.4 \mathrm{ab}$ & $8.54 \mathrm{ab}$ \\
\hline Wet Pink & $89.6 \mathrm{ab}$ & $132.8 \mathrm{abc}$ & $7.53 \mathrm{ab}$ \\
\hline Red 16023 & 50.1 bed & $60.3 \mathrm{acd}$ & $3.62 \mathrm{bc}$ \\
\hline Reinking & $98.1 \mathrm{ab}$ & $135.4 \mathrm{abc}$ & $7.91 \mathrm{ab}$ \\
\hline Green Favorite & $71.6 \mathrm{abcd}$ & 103.7 abed & $8.04 \mathrm{ab}$ \\
\hline Thong Dee & $85.9 \mathrm{abc}$ & 106.0 abcd & $6.20 \mathrm{abc}$ \\
\hline Pink 9551 & 35.1 bed & $52.9 \mathrm{~cd}$ & $3.93 \mathrm{bc}$ \\
\hline Siamese & 10.4 abcd & $82.9 \mathrm{abcd}$ & $5.51 \mathrm{abc}$ \\
\hline African & $100.5 \mathrm{ab}$ & $124.4 \mathrm{abc}$ & $7.34 \mathrm{ab}$ \\
\hline Tresca & $0 \mathrm{~d}$ & $0 \quad d$ & $0 \quad c$ \\
\hline Father Jerome & 64.8 abed & 56.8 acd & $5.71 \mathrm{abc}$ \\
\hline Pink 9552 & $66.3 \mathrm{abcd}$ & $108.8 \mathrm{abcd}$ & $7.43 a b$ \\
\hline Chinese & $43.7 \mathrm{bcd}$ & $83.1 \mathrm{abcd}$ & $5.11 \mathrm{bc}$ \\
\hline Ogami & $22.6 \mathrm{~cd}$ & $42.5 \mathrm{~cd}$ & $3.72 \mathrm{bc}$ \\
\hline Isabela Hybrid & $2.6 \mathrm{~d}$ & $42.8 \mathrm{~cd}$ & $3.68 \mathrm{bc}$ \\
\hline White 16026 & $77.3 \mathrm{abc}$ & $105.8 \mathrm{abcd}$ & $6.09 \mathrm{abc}$ \\
\hline
\end{tabular}

'Means in columns followed by the same letter do not differ significantly at the $5 \%$ probability level. 
have. In the present study only the parameters of fruit production, fruit weight and yield efficiency were considered. Results show that clones Dry Pink, Thong Dee White, African Seedling, Reinking and Wet Pink were superior, but production in almost all clones was excellent. Only clones Tresca, Ogami and Isabela Hybrid were consistently inferior in terms of the measured parameters.

Aspects of fruit quality, such as juice content, pulp color, pulp consistency, flavor, peel thickness, are also important for the final recommendation of a variety. A study of these parameters will be presented as a separate publication. 